\title{
An Alternative and Rapid Method for the Extraction of Nucleic Acids from Ixodid Ticks by Potassium Acetate Procedure
}

\author{
Islay Rodríguez ${ }^{1 *}$, Jorge Fraga ${ }^{1}$, Angel Alberto Noda $^{1}$, Milagro Mayet $^{2}$, Yanisia Duarte ${ }^{3}$, \\ Eduardo Echevarria ${ }^{1}$ and Carmen Fernández ${ }^{1}$ \\ ${ }^{1}$ Instituto de Medicina Tropical "Pedro Kourí"; La Habana - Cuba. ${ }^{2}$ Hospital Neumológico Benéfico Jurídico; La \\ Habana - Cuba ${ }^{3}$ Centro Nacional de Sanidad Agropecuaria; Mayabeque - Cuba
}

\begin{abstract}
Four variants of the potassium acetate procedure for DNA extraction from ixodid ticks at different stage of their life cycles were evaluated and compared with phenol-chloroform and ammonium hydroxide methods. The most rapid and most efficient variant was validated in the DNA extraction procedure from the engorged ticks collected from bovine, canine as well as from house ticks for the screening of Borrelia burgdorferi sensu lato, Anaplasma spp. and Babesia spp. The ammonium hydroxide procedure was used for non-engorged ticks. All the variants were efficient and allowed obtaining PCR-quality material according to the specific amplification of $16 S$ rRNA gene fragment of the original tick. DNA extracted from the ticks under the study was tested by multiplex PCR for the screening of tickborne pathogens. Anaplasma spp. and Babesia spp. amplification products were obtained from $29 / 48$ extracts. Ammonium hydroxide protocol was not efficient for two extracts. Detection of amplification products from the PCR indicated that DNA had been successfully extracted. The potassium acetate procedure could be an alternative, rapid, and reliable method for DNA extraction from the ixodid ticks, mainly for poorly-resourced laboratories.
\end{abstract}

Key words: Ticks, PCR, DNA extraction

\section{INTRODUCTION}

Hard ticks (Acari: Ixodidae) are ectoparasitic arthropods and vectors of many pathogenic microorganisms (Borrelia, Anaplasma, Ehrlichia, Babesia and Theileria species), affecting both the humans and animals. Diseases transmitted to the livestock by ticks constitute a major factor limiting animal production. For the humans, they can cause toxic conditions such as paralysis, toxicoses, irritation and allergy, and a great variety of infectious diseases as well (Estrada-Peña and Jongejan 1999; Parola and Raoult 2001; Elston 2010; Briciu et al. 2011).
Molecular detection of pathogens in ticks is primarily based on the amplification of DNA by polymerase chain reaction (PCR) from the targeted microorganism and followed by restriction fragment length polymorphism, reverse line blotting, or by DNA sequencing assays for the specific identification of species. The step for tick DNA extraction is often troublesome because hard ticks possess a chitinous exoskeleton that must be disrupted prior to extraction, the engorged ticks present possible Taq-polymerase inhibitors and the genomic DNA extracted appears to be highly susceptible to degradation. That is why standardized, efficient, and reliable DNA

\footnotetext{
*Author for correspondence: islay@ipk.sld.cu
} 
extraction methods are necessaries (Sparagano et al. 1999; Hill and Gutierrez 2003).

Several commercial and non-commercial methods have been reported for the extraction of DNA from the ticks and the pathogens they carry. Currently, the extraction with ammonium hydroxide and heating is widely used and reported in many studies because it has the advantage of being a very simple, rapid, and inexpensive method, which has been proved to be useful for the ticks from vegetation, but the PCR inhibition risk is present when they are collected from the animal reservoirs, or they are in engorged stage (Rauter and Hartung 2005). Other methods require previous steps before the extraction protocol because they include crushing of the ticks, bisection, or freezing, and enzymatic protein degradation. For example, the conventional phenol-chloroform procedure is useful for any stage and origin of the tick, but it involves costly and time-consuming steps and use of potentially health hazardous chemicals (phenol and chloroform), which make this process difficult to be carried out (Saiki 1990; Sparagano et al. 1999; Halos et al. 2004). The commercial methods are easier to perform, safer, and more rapid although there are slight differences in the hands-on time from one to another (Mahittikorn et al. 2005), but they are not accessible to poorly-resourced laboratories.

The potassium acetate procedure has been broadly used for the DNA extraction from the plants. It yields enough DNA to test a large number of markers and it has been recommended in the cases when many markers are to be tested on the same samples (Dellaporta et al. 1983; EchevarríaMachado et al. 2005; Detlef and Glazebrook 2009; Madhan Shankar et al. 2009). This method has also been reported for the DNA extraction from mosquitoes and triatomines with excellent results (Fraga et al. 2004; De Armas et al. 2005; Fraga et al. 2011).

The aims of this study were to evaluate the potassium acetate procedure as an alternative and rapid DNA extraction from the ticks in order to test its efficiency and practicability in obtaining the PCR-quality material, comparing it with ammonium hydroxide and phenol-chloroform procedures, and to validate this method for the extraction of DNA for the later detection of tickborne pathogens.

\section{MATERIALS AND METHODS}

\section{Ticks}

Nymphs, male and female adult (engorged and non-engorged) ticks from Rhipicephalus (Boophilus) microplus and R. sanguineus species, collected and identified two weeks before this study and preserved in 70\% ethanol at the National Laboratory of Spirochetes and Special Pathogens at the Pedro Kourí Tropical Medicine Institute, Havana, Cuba, were used for the evaluation. Each individual tick was washed in $70 \%$ ethanol again, rinsed with sterile water and dried. The ticks used for DNA extractions with potassium acetate and phenol-chloroform were frozen with liquid nitrogen and disrupted mechanically using $1.5 \mathrm{~mL}$ plastic tubes with a pestle.

\section{Extraction of tick nucleic acids}

For the extraction with potassium acetate, four variants of the protocol used by De Armas et al. (2005) were evaluated. The differences among the procedures for each variant are summarized in the Table 1 . Briefly, $500 \mu \mathrm{L}$ of lysis buffer $[0.1 \mathrm{M}$ Tris- $\mathrm{HCl}$ (pH 8.25), $0.05 \mathrm{M}$ EDTA, $0.2 \mathrm{M}$ sucrose, $0.5 \%$ SDS] with and without proteinase K (10 $\mathrm{mg} / \mathrm{mL}$ ) was added to each tick lysate. Suspensions without proteinase $\mathrm{K}$ were incubated at $65^{\circ} \mathrm{C}$ for $10 \mathrm{~min}$ and those with proteinase $\mathrm{K}$ at $56^{\circ} \mathrm{C}$ for one hour. Afterwards, $120 \mu \mathrm{L}$ of $5 \mathrm{M}$ potassium acetate was added to each one and these were incubated in ice during $10 \mathrm{~min}$. Then, they were centrifuged at $12000 \mathrm{xg}$ for $10 \mathrm{~min}$ and the supernatants were collected.

Table 1 - Summary of the differences among the potassium acetate procedure variants evaluated for the extraction of DNA ticks.

\begin{tabular}{|c|c|c|c|c|}
\hline & $\begin{array}{l}\text { Variant 1 } \\
\text { (original } \\
\text { procedure) }\end{array}$ & $\begin{array}{c}\text { Variant } \\
2\end{array}$ & $\begin{array}{c}\text { Variant } \\
\mathbf{3}\end{array}$ & $\begin{array}{c}\text { Variant } \\
4\end{array}$ \\
\hline $\begin{array}{l}\text { Lysis buffer } \\
\text { with proteinase } \\
\mathrm{K}\end{array}$ & No & No & Yes & Yes \\
\hline $\begin{array}{l}\text { Incubation with } \\
\text { lysis buffer }\end{array}$ & $\begin{array}{c}10 \mathrm{~min} / \\
65^{\circ} \mathrm{C}\end{array}$ & $\begin{array}{c}10 \mathrm{~min} / \\
65^{\circ} \mathrm{C}\end{array}$ & $\begin{array}{c}1 \mathrm{~h} / \\
56^{\circ} \mathrm{C}\end{array}$ & $\begin{array}{c}1 \mathrm{~h} / \\
56^{\circ} \mathrm{C}\end{array}$ \\
\hline $\begin{array}{l}\text { Incubation for } \\
\text { the } \\
\text { precipitation of } \\
\text { nucleic acids }\end{array}$ & $10 \mathrm{~min} / \mathrm{RT}$ & $\begin{array}{c}10 \mathrm{~min} / \\
-20^{\circ} \mathrm{C}\end{array}$ & $\begin{array}{l}10 \mathrm{~min} / \\
\mathrm{RT}\end{array}$ & $\begin{array}{c}10 \mathrm{~min} / \\
-20^{\circ} \mathrm{C}\end{array}$ \\
\hline
\end{tabular}

RT: room temperature 
For the precipitation of nucleic acids, $35 \mu \mathrm{L}$ of $4 \mathrm{M}$ sodium acetate and $0.25 \%$ acrylamide mix and 1.0 $\mathrm{mL}$ of absolute ethanol were added to each supernatant, which were then incubated for $10 \mathrm{~min}$ either at room temperature or at $-20^{\circ} \mathrm{C}$, followed by a centrifugation at $12000 \mathrm{xg}$ for $20 \mathrm{~min}$. The pellets were washed with $500 \mu \mathrm{L}$ of $70 \%$ ethanol and air-dried at room temperature. Finally, the extracts were re-suspended with $25 \mu \mathrm{L}$ of $1 \mathrm{X}$ TE buffer ( $1 \mathrm{mM}$ Tris-HCl pH 8.0, $1 \mathrm{mM}$ EDTA), and stored at $-20^{\circ} \mathrm{C}$ until use.

DNA extraction using phenol-chloroform procedure was applied according Fraga et al. (2004) with modification. Briefly, $400 \mu \mathrm{L}$ of lysis buffer $[50 \mathrm{mM}$ Tris- $\mathrm{HCl}$ (pH 8.25), $25 \mathrm{mM}$ EDTA, $25 \mathrm{mM} \mathrm{NaCl}, 1 \%$ SDS, proteinase K (500 $\mu \mathrm{g} / \mathrm{mL})]$ was added to each tick lysate. The mixtures were vigorously vortexed and incubated at $56^{\circ} \mathrm{C}$ for $2 \mathrm{~h}$. Then, a phenol-chloroformisoamilic alcohol mix (25:24:1) was added, homogenized and centrifuged at $12000 \mathrm{xg}$ for 10 min. The upper aqueous layer was removed and taken to a new tube, avoiding the phenol interface. It was washed with $400 \mu \mathrm{L}$ of chloroformisoamilic alcohol (24:1), centrifuged and the aqueous layer was transferred to a new tube. After that, two volumes of cold absolute ethanol and 40 $\mu \mathrm{L}$ of $3 \mathrm{M}$ sodium acetate $(\mathrm{pH} 5.0)$ were added, vortexed briefly, and incubated at $-20^{\circ} \mathrm{C}$ for 30 min for nucleic acid precipitation. The tubes were centrifuged at $12000 \mathrm{xg}$ for $5 \mathrm{~min}$ and the supernatant was discarded. The pellet was washed with $400 \mu \mathrm{L}$ of $70 \%$ ethanol, air-dried at room temperature, re-suspended with $30 \mu \mathrm{L}$ of $1 \mathrm{X} \mathrm{TE}$ buffer and stored at $-20^{\circ} \mathrm{C}$ until use.

In the ammonium hydroxide procedure, the intact ticks were boiled at $100^{\circ} \mathrm{C}$ for $15 \mathrm{~min}$ in $100 \mu \mathrm{L}$ of $0.7 \mathrm{M}$ ammonium hydroxide in a heating block. The tubes were cooled at room temperature and left open at $100^{\circ} \mathrm{C}$ for $15 \mathrm{~min}$ to allow ammonia to evaporate (Guy and Stanek 1991; Rijpkema et al. 1996; Humair et al. 2007). The extracts were stored at $-20^{\circ} \mathrm{C}$ until use.

\section{Evaluation of the efficiency of the nucleic acid extraction procedures}

The efficiency of each nucleic acid extraction was evaluated by two methods: a) electrophoresis in $0.8 \%(\mathrm{w} / \mathrm{v})$ agarose gels containing ethidium bromide and visualized under ultraviolet light, and b) amplification by PCR of a fragment of the tick mitochondrial 16S rRNA gene using the specific primers reported by Halos et al. (2004). Each reaction was carried out in $25 \mu \mathrm{L}$ volume containing $1 \mu \mathrm{M}$ of each primer, $1 \mathrm{X}$ PCR buffer $(0.5 \mathrm{M} \mathrm{KCl}, 0.5 \mathrm{M}$ Tris- $\mathrm{HCl} \mathrm{pH} 8.0,25 \mathrm{mM}$ $\mathrm{MgCl}_{2} \times 6 \mathrm{H}_{2} \mathrm{O}, 2 \mathrm{mM}$ of each dNTP, $2.0 \mathrm{mg} / \mathrm{mL}$ BSA), $0.75 \mathrm{U}$ of Taq DNA polymerase (Roche Diagnostics GmbH, Germany), $5 \mu \mathrm{L}$ of the DNA extract and sufficient quantity of sterile double distilled water. DNA amplifications were performed in a personal thermocycler (Eppendorf, Germany) using the program reported previously (Halos et al. 2004). DNA amplicon electrophoresis was carried out in $2 \%(\mathrm{w} / \mathrm{v})$ agarose gels.

\section{Selection of the best variant for the potassium acetate extraction}

It was mainly based on the shorter completion time (total time required in the laboratory, including incubation periods) of the procedure and on the preservation of the DNA survival during the extraction process.

\section{Screening of $B$. burgdorferi sensu lato, Anaplasma spp. and Babesia spp. in Cuban hard ticks}

A preliminary screening of tick-borne pathogens in 155 ticks collected during December 2008 to May 2009 from bovines, canines and in a house of different localities of Havana and Artemisa provinces, Cuba was done. Ticks were washed in $70 \%$ ethanol, rinsed with sterile water and air dried. The engorged female ticks (individual, or pool of two arthropods) were subject to the extraction with the selected variant of potassium acetate procedure; while larvae, nymphs, male and non-engorged female ticks were grouped in two to four arthropods (according to the size and stage of life cycle) per pool and treated with the ammonium hydroxide method. The genomic DNA extraction was controlled by the amplification of the fragment of tick mitochondrial 16S rRNA gene. The DNA extracts with quality for PCR were used as template in a multiplex PCR for the detection of B. burgdorferi sensu lato, Anaplasma spp. and Babesia spp. This assay was designed and evaluated previously in collaboration with the Laboratory of Eco-Epidemiology of Parasites of the Biology Institute at the Neuchatel University, Switzerland. Each $25 \mu \mathrm{L}$ of the reaction mixture contained $1 \mu \mathrm{M}$ of primers 16S8FE/GAB1-new (Schouls et al. 1999; Bekker et al. 2002) for Anaplasma spp., $0.1 \mu \mathrm{M}$ of $\mathrm{P} 1 / \mathrm{P} 2$ primers for $B$. burgdorferi sensu lato (Postic et al. 1994) and 
Bab1/Bab2 (non-published new design) for Babesia spp., $0.4 \mathrm{mM}$ of dNTP, $2 \mathrm{mM}$ of $\mathrm{MgCl}_{2}$, $0.03 \mathrm{U} / \mu \mathrm{L}$ of $\mathrm{Taq}$ DNA polymerase, enzyme buffer, sterile double distilled water and $5 \mu \mathrm{L}$ of extracted DNA. Cycling conditions included an initial denaturation at $94^{\circ} \mathrm{C}$ for $3 \mathrm{~min}$, followed by 50 cycles of a $30 \mathrm{sec}$ denaturation at $94^{\circ} \mathrm{C}, 30 \mathrm{sec}$ annealing at $53^{\circ} \mathrm{C}$ and $1 \mathrm{~min}$ extension at $72^{\circ} \mathrm{C}$, ending with a $10 \mathrm{~min}$ final extension step at $72^{\circ} \mathrm{C}$. DNA bands were stained with ethidium bromide in $2 \%(\mathrm{w} / \mathrm{v})$ agarose gels and visualized by UV transillumination. The achieved specific amplification products of 226-256 base pairs (bp) for B. burgdorferi sensu lato, $492-498$ bp for Anaplasma spp. and 925-995 bp for Babesia spp. were considered as positive results. Negative and positive controls were included in all the runs.

\section{RESULTS AND DISCUSSION}

The washing of ticks is the first step to obtain a good nucleic acid extract from them, due to the fact that the DNA derived from non-target organisms present on the surface of ticks may give amplicons with some primers, which causes contamination and false positive reactions with the PCR technique. Other washing forms may include iodine, sodium hypochlorite, or hydrogen peroxide (Sparagano et al. 1999). For the nucleic acid extraction methods that use enzymatic protein degradation before nucleic acid extraction, it is necessary to associate this procedure with an initial fine crushing, due to the need for mechanical destruction of the polysaccharide chains of the chitin of the tick exoskeleton (Halos et al. 2004).

When the nucleic acid extracts obtained by potassium acetate variants were run in electrophoresis, only RNA were visible from all stages of ticks and no differences among the four variants were observed. On the other hand, in the phenol-chloroform extracts, RNAs were also observed in all the extracts while DNA was slightly visible for fed, or engorged female $R$. microplus adult extracts. Neither RNA nor DNA from ammonium hydroxide extractions was visible on agarose gels. The results found for the phenolchloroform procedure could be due to the difference of size among the life stages and the sex of the ticks and fed female adults were the largest. Nevertheless, the electrophoresis was not a reliable method for evaluating the efficiency of the different assayed protocols; therefore, the amplification of DNA was used by PCR.

Specific amplifications of a $320 \mathrm{bp}$ DNA fragment were successfully obtained for each potassium acetate extract. Whatever was the variant used no difference in DNA extraction was observed according to the lysis buffer composition (with or without proteinase $\mathrm{K}$ ) and DNA precipitation conditions (Fig.1).

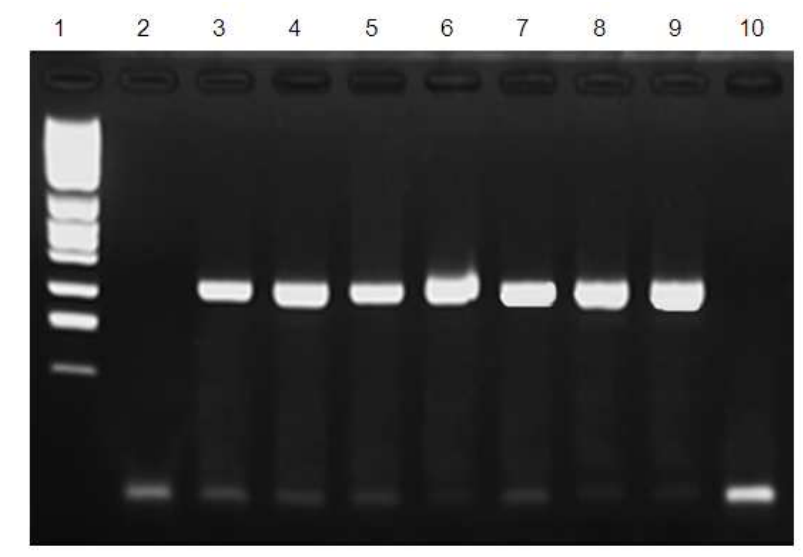

Figure 1 - Tick mitochondrial 16S rRNA PCR (320 bp). Lanes: 1, 100 bp-ladder (Promega); 23 , tick DNA extracts using ammonium hydroxide method; 4-5, tick DNA extracts using phenol-chloroform method; 6-9, tick DNA extracts using each variant ( 1 to 4 ) of potassium acetate method; 10, negative control (water).

According to the results obtained by each potassium acetate variant, the completion time and the conditions for the preservation of the DNA survival, if fine crushing was made, then lysis buffer without proteinase $\mathrm{K}$ (incubation time $=10$ min) should be used, but if the crushing was not adequate, it would be necessary to use proteinase $\mathrm{K}$ in the lysis buffer and the incubation time should then be one hour. For the DNA precipitation, incubation should be at $-20^{\circ} \mathrm{C}$ for 10 min as DNA could be preserved at this temperature. The specific amplification of the fragment of the $16 \mathrm{~S}$ mitochondrial gene also confirmed the DNA extraction from all the processed ticks by phenol-chloroform and ammonium hydroxide procedures, except from the engorged female ticks when ammonium hydroxide was used (Fig. 1), in which the presence of blood caused the inhibition of the enzyme Taq during the amplification process. 
The amplification of a fragment of the tick mitochondrial 16S rRNA gene was a good control to confirm the efficiency of DNA extraction. This is an important step for the studies in which detection of DNA of pathogens is carried out using the PCR amplification. This confirmed the quality of the DNA amplification as well as the absence of potentially inhibitory factors (Hubbard et al. 1995; Hill and Gutierrez 2003; Halos et al. 2004). The PCR results confirmed that electrophoresis in $0.8 \%$ agarose gel was not a successful method for demonstrating the efficiency of the nucleic acid extraction methods from ticks. Extraction efficiency should have been also evaluated with a spectrophotometer for the quantification of the DNA yield from each technique, but it was not possible due to the lack of equipment. There are several studies that the genomic DNA obtained by the potassium acetate procedure has an excellent quality as target in molecular techniques based on amplification by the PCR such as the random amplified polymorphic DNA analysis (De Armas et al. 2005). Taking in account the advantages of potassium acetate procedure regarding the phenolchloroform and the results of the current evaluation, the use of this protocol for DNA extraction from engorged ticks could be useful, and also the ammonium hydroxide method for non-engorged ticks, mainly in poorly-resourced laboratories.

As expected, all the ticks collected for the preliminary screening of tick-borne pathogens from the bovines were $R$. microplus (57) and the rest were $R$. sanguineus (98). There were ten engorged female ticks and 145 in other stages. In total, 48 DNA extracts were obtained.

All the DNA extracts obtained by the potassium acetate procedure (variant 2) showed a band of $320 \mathrm{bp}$ in the $2 \%(\mathrm{w} / \mathrm{v})$ agarose gel electrophoresis as a result of the tick mitochondrial 16S rRNA PCR. This indicated that the DNA had been successfully extracted without the carry-over of inhibitors to the reaction. However, two DNA extracts obtained by the ammonium hydroxide procedure were negatives for PCR, due to either the presence of inhibitory material in the extracts, or due to non-effective DNA extractions. It would be important to remember that the ticks (larvae, nymphs and adults), except one, were infesting the animals and there were always some rest of blood in the digestive tract. Thus, in case of ticks from the animals, the method used should eliminate all the possible inhibitory material similar to the potassium acetate method. Hubbard et al. (1995) evaluated a rapid extraction method of nucleic acids that combined guanidinium thiocyanate and diatomaceous earth and found good results when the extraction efficiency was monitored by the detection of tick DNA.

Amplification products corresponding to Anaplasma spp. and Babesia spp. (Fig. 2) were generated for $25 / 48$ and $4 / 48$ extracts, respectively; four of them were obtained by the potassium acetate procedure. B. burgdorferi sensu lato was not identified. The DNA of Anaplasma spp. was detected in the ticks from bovine, canines, and the house tick; nevertheless Babesia spp. was detected only in the ticks collected from canines.

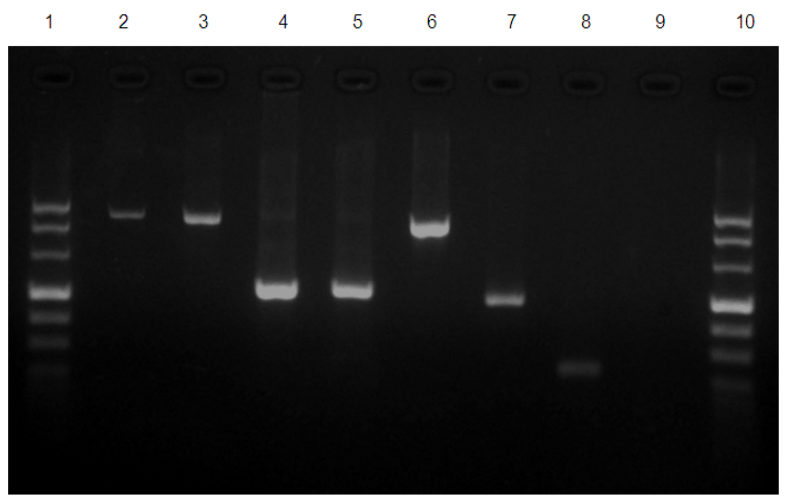

Figure 2 - Multiplex PCR for Borrelia burgdorferi sensu lato (226-256 bp), Anaplasma spp. (492-498 bp) and Babesia spp. (925-995 bp). Lanes: 1 and 10, marker VI (Roche); 2-3, amplicon from ticks infected by Babesia spp.; 4-5, amplicon from ticks infected by Anaplasma spp.; 6-8, positive controls (B. microti, A. phagocitophylum and $B$. garinii, respectively); 9, negative control (water).

\section{CONCLUSIONS}

These results suggested the use of the potassium acetate method as a new alternative for the extraction of the genomic DNA from the ticks as it allowed eliminating all the blood residuals, debris, and other possible inhibitory materials from the ticks and permitted detecting the DNA from tickborne pathogens. Therefore, this could be a rapid and reliable method for DNA extraction from ixodid, or hard ticks, mainly for poorly-resourced laboratories. 


\section{ACKNOWLEDGMENTS}

We thank Dr. Lise Gern for her kind help with some Molecular Biology's reagents and to Pr. Armando Martínez for his exhaustive revision of the English.

\section{REFERENCES}

Bekker CP, De Vos S, Taoufik A, Sparagano OA, Jongejan F. Simultaneous detection of Anaplasma and Ehrlichia species in ruminants and detection of Ehrlichia ruminantium in Amblyomma variegatum ticks by reverse line blot hybridization. Vet Microbiol. 2002; 89: 223-238.

Briciu VT, Titilincu A, Tatulescu DF, Carstina D, Lefkaditis M, Mihalca AD. First survey on hard ticks (Ixodidae) collected from humans in Romania: possible risks for tick-borne diseases. Exp Appl Acarol. 2011; 54: 199-204.

De Armas Y, Rodríguez MM, Bisset JA. Modification of a method to extract genomic DNA from Aedes aegypti (Diptera: Culicidae). Rev Colombiana Entomol. 2005; 31, 203-206.

Dellaporta SL, Wood J, Hicks JB. A plant DNA Minipreparation: version II. Plant Mol Biol Rep. 1983; 1: 19-21.

Detlef W, Glazebrook J. Dellaporta Miniprep for Plant DNA Isolation. Cold Spring Harb Protoc; 2009.

Echevarría-Machado I, Sánchez-Cach LA, HernándezZepeda C, Rivera-Madrid R, Moreno-Valenzuela OA. A simple and efficient method for isolation of DNA in high mucilaginous plant tissues. Mol Biotechnol. 2005; 31: 129-135.

Elston DM. Tick bites and skin rashes. Curr Opin Infect Dis. 2010; 23: 132-138.

Estrada-Peña A, Jongejan F. Ticks feeding on humans: a review of records on human-biting Ixodoidea with special reference to pathogen transmission. Exp Appl Acarol. 1999; 23: 685-715.

Fraga J, Rodríguez J, Fuentes O, Castex M, FernándezCalienes A. Comparison among 5 methods for the extraction of Triatominae DNA: its use in the random amplified polymorphic DNA technique. Rev Cubana Med Trop. 2004; 56: 208-213.

Fraga J, Rodríguez J, Fuentes O, Hernández Y, Castex M, González R, Fernández-Calienes A. Genetic variability of Triatoma flavida and Triatoma bruneri (Hemiptera: Reduviidae) by RAPD-PCR technique. Rev Inst Med Trop Sao Paulo. 2011; 53: 19-24.

Guy EC, Stanek G. Detection of Borrelia burgdorferi in patients with Lyme disease by the polymerase chain reaction. J Clin Pathol. 1991; 44: 610-611.

Halos L, Jamal T, Vial L, Maillard R, Suau A, Le Menach A, Boulouis HJ, Vayssier-Taussat M. Determination of an efficient and reliable method for
DNA extraction from ticks. Vet Res. 2004; 35: 709713.

Hill CA, Gutierrez JA. A method for extraction and analysis of high quality genomic DNA from ixodid ticks. Med Vet Entomol. 2003; 17: 224-227.

Hubbard MJ, Cann KJ, Wright DJM. Validation and rapid extraction of nucleic acids from alcoholpreserved ticks. Exp Appl Acarol. 1995; 19: 473-478.

Humair PF, Douet V, Morán-Cardenas F, Schouls L, Van de Pol I, Gern L Molecular identification of blood meal source in Ixodes ricinus ticks using $12 \mathrm{~S}$ rDNA as a genetic marker. J Med Entomol. 2007; 44: 869-880.

Madhan Shankar SR, Sugumaran G, Kalaiyarasu T, Bubna N. A rapid method for isolation of high quality DNA from leaves of Gmelina arborea (Roxb) for molecular analysis. Int J Biotechnol Appl. 2009; 1: 16-19.

Mahittikorn A, Wickert H, Sukthana Y. Comparison of five DNA extraction methods and optimization of a B1 gene nested PCR (nPCR) for detection of Toxoplasma gondii tissue cyst in mouse brain. Southeast Asian J Trop Med Public Health. 2005; 36: 1377-1382.

Parola P, Raoult D. Ticks and tickborne bacterial diseases in humans: an emerging infectious threat. Clin Infec Dis. 2001; 32: 897-928.

Postic D, Assous MV, Grimont PAD, Baranton G. Diversity of Borrelia burgdorferi sensu lato evidenced by restriction fragment length polymorphism of $r r f(5 S)-r r l(23 S)$ intergenic spacer amplicons. Int J Syst Bacteriol. 1994; 44: 743-752.

Rauter C, Hartung T. Prevalence of Borrelia burgdorferi sensu lato genospecies in Ixodes ricinus ticks in Europe: a metaanalysis. Appl Environ Microbiol. 2005; 71: 7203-7216.

Rijpkema SG, Golubic D, Molkenboer MJ, Verbeek-De Kruif N, Schellekens JF. Identification of four genomic groups of Borrelia burgdorferi sensu lato in Ixodes ricinus ticks collected in a Lyme Borreliosis endemic region of northern Croatia. Exp Appl Acarol. 1996; 20: 23-30.

Saiki RK. Amplification of genomic DNA. In: Iinnis MA, Gelfand DH, Sninski JJ, White TJ. PCR Protocols: A Guide to Methods and Applications. Academic Press, San Diego; 1990.

Schouls LM, Van de Pol I, Rijpkema SGT, Schot CS. Detection and identification of Ehrlichia, Borrelia burgdorferi sensu lato, and Bartonella species in Dutch Ixodes ricinus ticks. J Clin Microbiol. 1999; 37: 2215-2222.

Sparagano OAE, Allsopp MTEP, Mank RA, Rijpkema SGT, Figueroa JV, Jongejan F. Molecular detection of pathogen DNA in ticks (Acari: Ixodidae): a review. Exp Appl Acarol. 1999; 23: 929-960.

Received: May 20, 2013; Accepted: January 17, 2014. 